Article

\title{
Bioremediation of Artificial Diesel-Contaminated Soil Using Bacterial Consortium Immobilized to Plasma-Pretreated Wood Waste
}

\author{
Ravit Farber ${ }^{1}$, Alona Rosenberg ${ }^{1}$, Shmuel Rozenfeld ${ }^{1}{ }^{1}$, Gabi Banet ${ }^{2}$ and Rivka Cahan ${ }^{1, *}$ \\ 1 Department of Chemical Engineering and Biotechnology, Ariel University, Ariel 40700, \\ Israel; ravitf@ariel.ac.il (R.F.); alonar@ariel.ac.il (A.R.); shmuelro@ariel.ac.il (S.R.) \\ 2 Dead Sea-Arava Science Center, Arava 86910, Israel; gabib@adssc.org \\ * Correspondence: rivkac@ariel.ac.il; Tel.: +972-54-7740293
}

Received: 21 August 2019; Accepted: 26 October 2019; Published: 28 October 2019

\begin{abstract}
Bioaugmentation is a bioremediation option based on increasing the natural in-situ microbial population that possesses the ability to degrade the contaminating pollutant. In this study, a diesel-degrading consortium was obtained from an oil-contaminated soil. The diesel-degrading consortium was grown on wood waste that was plasma-pretreated. This plasma treatment led to an increase of bacterial attachment and diesel degradation rates. On the 7th day the biofilm viability on the plasma-treated wood waste reached $0.53 \pm 0.02 \mathrm{OD} 540 \mathrm{~nm}$, compared to the non-treated wood waste which was only $0.34 \pm 0.02$. Biofilm attached to plasma-treated and untreated wood waste which was inoculated into artificially diesel-contaminated soil $(0.15 \% \mathrm{~g} / \mathrm{g})$ achieved a degradation rate of $9.3 \mathrm{mg} \mathrm{day}^{-1}$ and $7.8 \mathrm{mg} \mathrm{day}^{-1}$, respectively. While, in the soil that was inoculated with planktonic bacteria, degradation was only $5.7 \mathrm{mg} \mathrm{day}^{-1}$. Exposing the soil sample to high temperature $\left(50^{\circ} \mathrm{C}\right)$ or to different soil acidity did not influence the degradation rate of the biofilm attached to the plasma-treated wood waste. The two most abundant bacterial distributions at the family level were Xanthomonadaceae and Sphingomonadaceae. To our knowledge, this is the first study that showed the advantages of biofilm attached to plasma-pretreated wood waste for diesel biodegradation in soil.
\end{abstract}

Keywords: bioremediation; bioaugmentation; biofilm; diesel; contaminated soil

\section{Introduction}

The motivation for our study was an oil-spill disaster that occurred in December 2014, next to the Evrona Nature Reserve in southern Israel. An oil pipeline a few kilometers away was breached, releasing $5000 \mathrm{~m}^{3}$ of crude oil into the reserve. During the remediation activities, an older spill was found $3 \mathrm{~km}$ further south, traced back to 1975 and holded 8000-10,000 cubic meters of contamination; for unknown reasons it had been ignored. About a third of the 1975 spill is estimated to still be present, enriching the soil with oil-degrading microorganisms. Oil contamination can be naturally biodegraded with indigenous oil-degrading bacteria. However, enrichment of those in-situ bacteria with exogenous oil-degrading bacteria may be a key factor for increasing bioremediation rates.

Diesel fuel is a fraction of crude oil distilled between $200{ }^{\circ} \mathrm{C}$ and $350{ }^{\circ} \mathrm{C}$. It includes a mixture of aromatic compounds, alkanes, cyclic alkanes, and branched alkanes that contain $C_{9}-C_{25}$ per molecule. Accidental spills or leakage from pipelines and storage tanks often cause environmental contamination [1]. Diesel fuel is also considered highly toxic and carcinogenic [2]. Technologies for remediation of oil-contaminated soil are based on chemical, physical, and biological approaches. Chemical and physical methods may, however, create another kind of pollution, and they are often costly to implement [3]. Bioremediation is a biological approach considered to be an environmentally 
friendly and cost-effective alternative to physical and chemical treatments. Bioremediation technology is based on the ability of microorganisms to utilize toxic compounds (such as polychlorinated biphenyls, polycyclic aromatic hydrocarbons, phthalate esters, nitroaromatic pesticides, and petroleum hydrocarbons) as a source of carbon and energy. There are specific microorganisms or microbial consortia that can mineralize pollutants to $\mathrm{CO}_{2}$ and $\mathrm{H}_{2} \mathrm{O}$ [4-8].

Bioaugmentation is a bioremediation option based on increasing the natural in-situ microbial population in the contaminated environment [9]. The effectiveness of bioaugmentation is the subject of controversy. Successful petroleum hydrocarbon bioremediation using bioaugmentation was previously reported [10-13]. For example, Teng et al. (2010) showed that inoculation of Paracoccus sp. strain HPD-2 in soil contaminated by polycyclic aromatic hydrocarbons (PAHs) resulted in a $23.2 \%$ decrease in total PAH concentrations after 28 days (from 9942 to $7638 \mu \mathrm{g} \mathrm{kg}^{-1}$ in dry soil). The bioaugmented soil exhibited higher enzymatic activity and microbial biomass of the PAH-degrading bacteria. The clear differentiation of the enzymatic activities $(p<0.05)$ between the bioaugmented and control microcosms suggests that the PAH-degrading bacteria were restored in the bioaugmented soil [12].

However, other researchers reported the failure of exogenous microbial in-situ adaptation, described by a decline of the microbial concentration within a short time. The suggested explanation is that the microbial biomass produced in the lab and transferred to the contaminated site suffered from stress when introduced to the natural biotic and abiotic factors in the habitat [14-17]. Biodegradation of a mixture of PAHs was examined in soil with and without bioaugmentation, using individual bacteria, fungi, and a fungal consortium. In all cases, the low-molecular-weight hydrocarbons (naphthalene, anthracene, and phenanthrene) showed a rapid removal rate, without significant effect on the bioaugmentation. The same phenomenon was observed with the high-molecular-weight hydrocarbons (pyrene, benz[a]pyrene, and benz[a]anthracene). Bioaugmented soil with the isolated Aspergillus sp. resulted in a significant increase of benz[a]anthracene and benz[a]pyrene removal. This suggests that Aspergillus sp. may have some potential as a bioaugmentation agent [16].

In our study, we tried to overcome the stress on the bacterial consortium upon introduction into the contaminated soil by adding the bacteria as biofilm on wood waste instead of planktonic bacteria. Biofilms are microbial cells attached to surfaces that communicate through quorum-sensing signals and ease their adjustment to the environment [18]. A bacterial biofilm resists mechanical stress [19] and hydration [20], and can survive in nutrient-deficient conditions [21]. The bacterial attachment to a surface is the first step in biofilm formation. The topography and wettability of the surface, the bacterial cell-surface charges, and structures such as pili, fimbriae, flagella, and capsules, all influence the bacterial attachment [22-24]. A solid matrix for biofilm formation in bioremediation includes: Ca-alginate [25], activated carbon [26], a polyacrylonitrile membrane [27], geo-textile sheets [6], coal bottom ash [28], and wood waste [24].

In this study, a diesel-degrading consortium was obtained from soil contaminated in the 1975 oil spill found in the Evrona Nature Reserve (located in southern Israel). The obtained diesel-degrading bacteria may be used for further increasing bioremediation rates of the second oil spill in the same reserve. Bioaugmentation of individual bacteria in a bacterial consortium may be limited by the indigenous bacteria and by the in-situ chemical and physical conditions. We assume that bioaugmentation of biofilm on a substratum may overcome these limitations. In this study, wood waste, a cost-effective and natural material, served as the substratum for the diesel-degrading biofilm.

In a previous study published recently, we showed that exposure of wood waste to cold low-pressure nitrogen plasma led to an increase of the surface wettability and probable surface area, resulting in enhanced bacterial attachment and toluene degradation rates [24]. In the present study, the obtained bacteria were grown on plasma-pretreated wood waste in a mineral medium containing diesel as the sole carbon source. The wood waste with the covered biofilm was mixed with Hamra soil artificially contaminated with diesel fuel. The diesel biodegradation in the contaminated soil was evaluated in the presence of the biofilm grown on plasma-pretreated and nontreated wood waste, 
as well as planktonic bacteria. To our knowledge, this is the first study that shows the advantages of biofilms attached to plasma-pretreated wood waste for diesel biodegradation in soil.

\section{Materials and Methods}

\subsection{Preparation of Diesel Emulsion in Mineral Medium}

The preparation of diesel emulsion in mineral medium (MM) [8] or water was performed using a homogenizer ULTRA-TURBAX, T18 basic, (IKA, Königswinter, Germany) equipped with a high speed. The diesel and water were warmed up to $50{ }^{\circ} \mathrm{C}$ followed by homogenization for $5 \mathrm{~min}$. The emulsion was prepared immediately before each experiment

\subsection{Acquisition of a Diesel-Degrading Microbial Consortium from Oil-Polluted Soil}

Soil samples were collected from the site of an old (1975) terrestrial oil spill located at the margins of the Evrona Nature Reserve in southern Israel (29.6685N/34.99210E). Samples were collected aseptically from a depth of $\sim 10 \mathrm{~cm}$.

The collected soil was sifted in a strainer (pores of $1 \times 1 \mathrm{~mm}$ ) and $1 \mathrm{gr}$ soil was suspended in $100 \mathrm{~mL}$ of mineral medium (MM) supplied with $0.5 \%(v / v)$ diesel (MMD), followed by incubation at $30{ }^{\circ} \mathrm{C}$ with shaking at $170 \mathrm{rpm}$. After 14 days, the culture reached 0.8 OD $590 \mathrm{~nm}$. It was then diluted to 0.2 OD $590 \mathrm{~nm}$ in MMD, using a GENESYS 10S UV-Visible Scientific spectrophotometer (Thermo, Madison, WI, USA), and was grown for another cycle. Portions of the culture with the enriched diesel-degrading bacteria (evidenced by a greenish color) were frozen at $-80^{\circ} \mathrm{C}$ in $20 \%$ glycerol.

\subsection{Measuring Diesel Concentration with Gas Chromatography-Flame Ionization Detector (GC-FID) Analysis}

Headspace sampling was performed with an autosampler, COMBI-xt, CTC Analytics, (PAL SYSTEM, Zwingen, Switzerland). The headspace oven temperature was set at $140{ }^{\circ} \mathrm{C}$, while the loop and transfer line temperatures were set at $150{ }^{\circ} \mathrm{C}$. Vial equilibration time was $20 \mathrm{~min}$. The gas chromatography-flame ionization detector (GC-FID) analysis was performed using a Master GC-FID (DANI, Cologno Monzese, Italy). Separations were performed on a $30 \mathrm{~m} 0.53 \mathrm{~mm}$ column (RTX-5). The injector temperature was $200^{\circ} \mathrm{C}$ and the detector temperature was $340{ }^{\circ} \mathrm{C}$. The injection port was operated at a 1:6 split. The flow rate of the carrier gas (helium) was set at $5.0 \mathrm{~mL} \mathrm{~min}^{-1}$. Analyses were performed with an initial column temperature of $45^{\circ} \mathrm{C}$ held for $3 \mathrm{~min}$, followed by heating to $275^{\circ} \mathrm{C}$ (heating at a rate of $12{ }^{\circ} \mathrm{C} \mathrm{min}-1$ ), and holding at $275{ }^{\circ} \mathrm{C}$ for $12 \mathrm{~min}$. Total run time was $34.16 \mathrm{~min}$. The diesel fraction contained many peaks (about 18), and all the areas under the whole peaks were taken into account for calculating diesel degradation rates.

\subsection{Exposure to Cold Low-Pressure Nitrogen Plasma}

The wood waste was exposed to a radiofrequency (RF, $13.56 \mathrm{MHz})$ inductive-pressure nitrogen plasma cleaner discharge, PDC-3XG, MMT Corp, (Harrick, Ithca, NY, USA). The low-pressure discharge was sustained by an RF oscillating electric field, generated in the gas region at a pressure $(\mathrm{P})$ of ca. 1.0 Torr and a power of $18 \mathrm{~W}$ for $1 \mathrm{~min}$. Nitrogen (99.999\%) was supplied by Oxygen and Argon Works Ltd., Israel [29].

\subsection{Biofilm Formation on the Wood Waste}

Diesel-degrading bacteria were grown to log phase in MMD at $30^{\circ} \mathrm{C}$ with shaking at $170 \mathrm{rpm}$. The cultures were diluted to $0.2 \mathrm{OD}$ in a $100 \mathrm{~mL}$ bottle containing 10 chips of wood waste from a local pine tree (pieces of $0.06 \pm 0.002 \mathrm{~g}$, length of $5 \pm 0.5 \mathrm{~mm}$ and diameter of $3 \pm 0.3 \mathrm{~mm}$ ), followed by incubation at $30^{\circ} \mathrm{C}$ in a static mode for 7 days, except where otherwise noted. 


\subsection{Measurements of the Biofilm Viability}

The viability of the bacteria in the biofilm was analyzed using a colorimetric assay based on a reduction of the reagent 3-(4,5-dimethylthiazol-2-yl)-2,5-diphenyltetrazolium bromide (MTT) by the bacterial hydrogenases. When this reagent is reduced, its color turns from yellow to blue. Thus, viable bacteria in the biofilm turned to a blue color. The next step was dissolving the reduced MTT inside the bacteria by adding dimethyl sulfoxide (DMSO): $\mathrm{EtOH} \mathrm{(1:1),} \mathrm{resulting} \mathrm{in} \mathrm{a} \mathrm{blue} \mathrm{solution.}$ The intensity of this solution (proportional to the bacterial hydrogenase activity and bacterial number) was measured using a spectrophotometer at $540 \mathrm{~nm}$.

The wood waste with the attached biofilm (aged 7 days unless otherwise indicated) was gently soaked in phosphate-buffered saline (PBS) in order to remove the planktonic bacteria that was weakly attached to the biofilm. This step was followed by inserting the wood waste with the attached biofilm into a tube containing $2 \mathrm{~mL}$ MTT solution ( $5 \mathrm{mg} \mathrm{mL}^{-1}$ of MTT in $0.1 \mathrm{M} \mathrm{PBS,} \mathrm{pH} 7.4$ ) and incubating at room temperature $\left(24^{\circ} \mathrm{C}\right)$ in the dark for $2 \mathrm{~h}$. Then the wood waste was gently washed with PBS (by now the biofilm was colored blue). The reduced MTT in the bacteria was dissolved by adding $2 \mathrm{~mL}$ dimethyl sulfoxide (DMSO): $\mathrm{EtOH}$ (1:1) for $20 \mathrm{~min}$. The absorbance of the solution was examined using a spectrophotometer at $540 \mathrm{~nm}$ [28]. When the absorbance was higher than $1 \mathrm{OD}$, the sample was diluted and re-examined.

\subsection{Measuring the Turbidity of the Bacteria in the Biofilm Attached to the Wood Waste}

To evaluate the live bacterial amount in the biofilm that was attached to the wood waste, the turbidity (at $590 \mathrm{~nm}$ ) of the bacteria detached from the biofilm was examined. The bacterial amount in the biofilm was important for the experiments of diesel biodegradation by planktonic bacteria. This served as a planktonic control for comparing the diesel-degrading activity of the bacteria in the biofilm attached to the wood waste.

The plasma-pretreated wood waste with the attached biofilm was inserted into a tube containing MM (10 chips in $15 \mathrm{~mL}$ ) and placed in a sonication bath for $10 \mathrm{~min}$. The optical density of the detached bacteria in MM was found to be $0.8 \pm 0.05$ OD $590 \mathrm{~nm}$. It is important to note that the bare wood waste (10 chips, immediately after the bath sonication) was found by MTT analysis to have an optical density of $0.3 \pm 0.02$ at $540 \mathrm{~nm}$, similar to the original wood waste which was $0.25 \pm 0.02$. This result indicated that all the live bacteria were detached from the biofilm. In addition, the turbidity at $590 \mathrm{~nm}$ of the MM after sonication of the original wood waste (not used for biofilm formation) was $0.02 \mathrm{OD}$, indicating no release of wood particles to the solution during sonication. Thus, the optical density was only of detached bacteria. Thus, $15 \mathrm{~mL}$ of fresh planktonic bacteria $(0.8 \pm 0.05$ OD $590 \mathrm{~nm})$ were added to diesel-contaminated soil and served as a control to diesel degradation by biofilm on 10 chips of wood waste.

\subsection{Preparation of Artificially Diesel-Contaminated Soil for Biodegradation Experiments}

Hamra soil (a red, sandy clay loam common in Israel) was sifted in a strainer (pores of $1 \times 1 \mathrm{~mm}$ ), and a portion of soil (100 g, $\mathrm{pH}$ 6.8) was mixed (using a household mixer) with diesel emulsion for $5 \mathrm{~s}$, to prepare $0.15 \%$ and $0.6 \%$ diesel in $100 \mathrm{~g}$ soil $(\mathrm{g} / \mathrm{g})$. The soil was added to $50 \mathrm{~mL}$ tubes (the tubes were cut at the bottom to allow irrigation every 3 days). Each tube held 10 chips of wood waste (plasma-treated and non-treated) covered with a 7-day old biofilm. In addition, tubes containing diesel-contaminated soil were inoculated with planktonic bacteria of the same concentration as the biofilm, on 10 chips. The diesel biodegradation in the artificially contaminated soil took place during 2 weeks at $37^{\circ} \mathrm{C}$. To examine diesel evaporation and degradation by the indigenous bacteria, soil was mixed with the diesel emulsion without the addition of the diesel-degrading consortium.

When the Hamra soil was adjusted to $\mathrm{pH} 5$ and 8.0, appropriate aliquots of $1 \mathrm{M} \mathrm{HCl}$ and $\mathrm{Na}_{2} \mathrm{CO}_{3}$ $(0.01 \mathrm{M})$ were added into the soil [30]. Measurement of the soil acidity was performed in water using a pH meter. Air-dried Hamra soil (2 g contaminated with $0.15 \%$ diesel) was inserted into a beaker and 
$20 \mathrm{~mL}$ of double deionized water were added. The suspension was stirred intermittently for $30 \mathrm{~min}$, followed by standing for about $1 \mathrm{~h}$, at room temperature. Then, the electrode was placed into the clear supernatant, and the $\mathrm{pH}$ was recorded once the reading became stable.

\subsection{Microbial Community Based on $16 S$ rRNA Analysis}

The microbial community analysis of the original oil-contaminated soil, as well as the biofilm attached to the plasma-treated and untreated wood waste (prepared as described above), was performed by HyLabs Pvt Ltd., Israel. DNA was extracted with the DNeasy Powersoil kit (Qiagen), operated according to the manufacturer's instructions. A 16s library preparation for sequencing on Illumina was performed using a 2-step PCR protocol. In the first PCR, the v4 region of the 16S rRNA gene was amplified using the 16s 515F and 806R from the Earth Microbiome Project with CS1 and CS2 tails. The second PCR was done using the Fluidigm access array primers for Illumina, to add the adaptor and index sequences. Sequencing was done on the Illumina Miseq, using a v2-500 cycles kit to generate $2 \times 250$ paired-end reads. Demultiplexing was performed on Basespace (the Illumina cloud), to generate FASTQ files for each sample. The data was furthered analyzed using CLC Bio to generate operational taxonomic unit (OTU) and Abundance tables. The data for each sample were trimmed for quality and adaptor read-through sequences. The trimmed reads were merged and trimmed to a fixed length. The reads were then subjected to OTU picking using the Greengenes database, to generate the OTU and Abundance tables.

\subsection{Statistics}

Data are expressed as means \pm SD (standard deviation) of two different experiments and three replicates. The results were statistically analyzed using one-way analysis of variance (ANOVA).

\section{Results and Discussion}

The research hypothesis is that diesel-degrading soil bacteria may become enriched during a prolonged period of diesel contamination and that they can be used for enhancing diesel degradation in a recently contaminated area. In addition, biofilm offers an advantage over planktonic bacteria for bioremediation in extreme environments and high organic matter concentrations. Wood waste is organic matter that can serve as a substratum for diesel-degrading bacteria, as well as increasing soil aeration.

Recently in previous research, we showed that plasma treatment led to enhancement of the wood-waste surface hydrophilicity, which was measured by the apparent contact angle of water. SEM analysis of the plasma-treated wood waste showed a significant change in the internal surface topography. Wood waste that was exposed to plasma led to a 3.5-fold increase in biofilm viability of the exogenously added P. putida F1 in MM supplied with toluene, and a 1.6-fold increase in MM supplied with glucose, compared to the untreated wood waste. Similar results were obtained with B. cereus. The biofilms of P. putida and B. cereus grown on wood waste pretreated with plasma led to an increase of toluene degradation, compared to biofilms grown on untreated wood waste [24].

In the current study, diesel (a fraction of crude oil) was chosen for isolating a bacterial consortium from the soil of a 1975 oil spill. The obtained diesel-degrading bacteria may be further used for increasing bioremediation rates of a second oil spill in the Evrona Nature Reserve. The technology of plasma-treated wood waste for biofilm formation can be implemented for bioremediation of that diesel-contaminated soil or other pollutant with suitable biofilm.

\subsection{Bacterial Consortium Growth Curve in MM with Diesel as the Carbon Source}

The obtained bacterial consortium $(0.15$ OD $590 \mathrm{~nm})$ was grown in sealed bottles in mineral medium, supplemented with diesel (MMD, $0.5 \% v / v$ ) that served as the sole carbon and energy source. A bacterial consortium that was grown in mineral medium without a diesel supplement served as the control. The bacterial consortium was incubated for 3 weeks at $30^{\circ} \mathrm{C}$ with agitation at 
$170 \mathrm{rpm}$. At regular intervals, the bacterial growth and diesel degradation were determined using a spectrophotometer and GC-FID, respectively. As depicted in Figure 1, the bacterial consortium reached $0.78 \pm 0.08 \mathrm{OD} 590 \mathrm{~nm}$ on the 15 th day; a reduction of the OD to $0.5 \pm 0.02$ was observed at the end of the experiment (probably a result of diesel depletion). At the end of the experiment, the residual diesel was $26 \%$ and the degradation rate was $1.6 \mathrm{mg}$ day $^{-1}$. In the control sample, where the bacterial consortium was grown without diesel as the carbon and energy source, the optical density was about 0.15 OD $590 \mathrm{~nm}$, which remained stable until the end of the experiment.

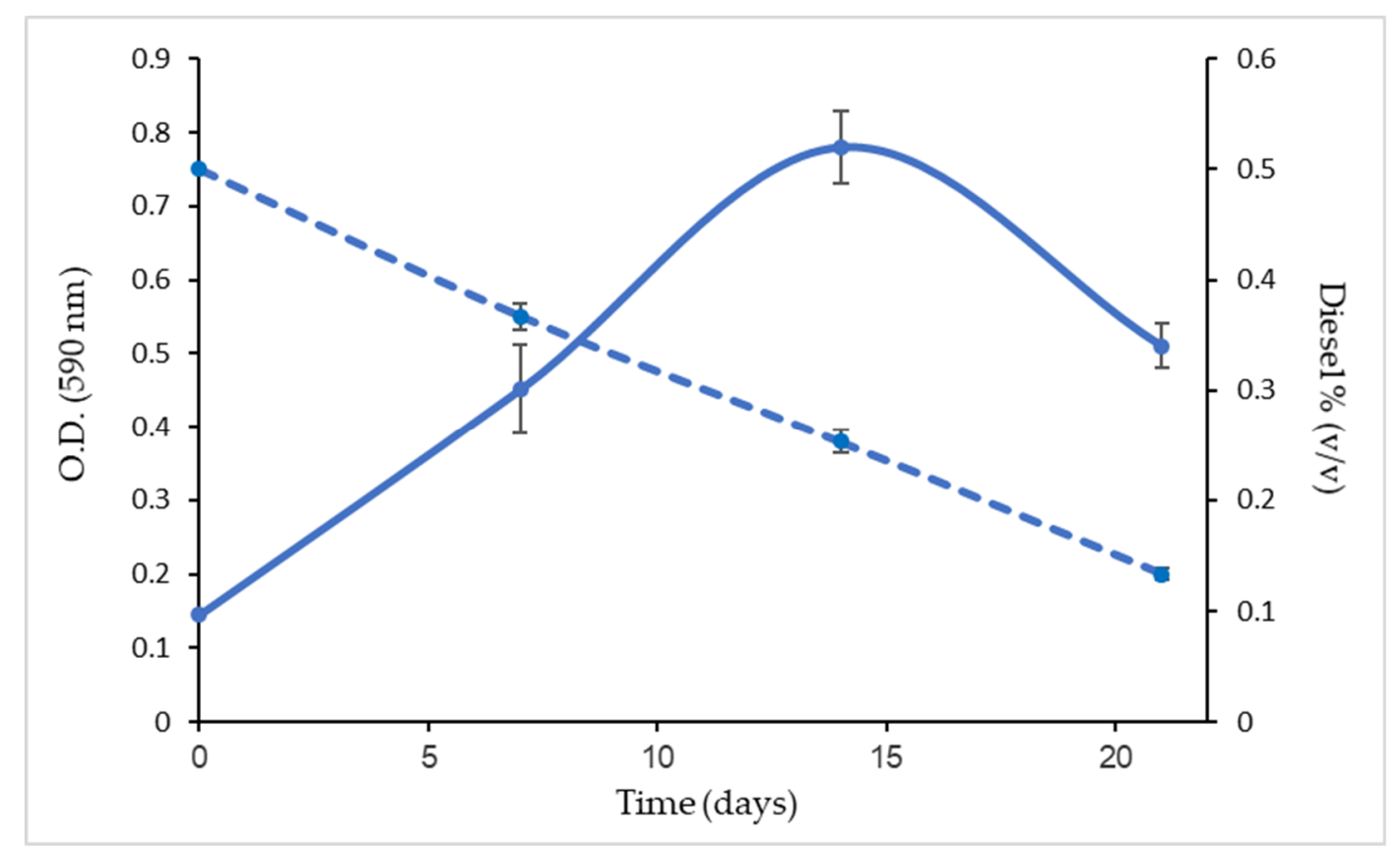

Figure 1. The obtained diesel-degrading consortium growth curve in mineral medium (MM) supplied with $0.5 \%(v / v)$ diesel (MMD).

The obtained diesel-degrading consortium was also grown on wood waste, and the biofilm on this substratum was applied to biodegradation of the artificially diesel-contaminated soil. The biofilm showed the potential to overcome harsh environmental conditions, such as extreme temperatures and soil acidity.

Biodegradation of environmental pollutants in soil is a slow process, influenced by abiotic factors and by a low abundance of indigenous pollutant-degrading microorganisms. Nutrients and oxygen supplementation, adjustment of $\mathrm{pH}$ and temperature (biostimulation), and microbial inoculation (bioaugmentation) were reported to increase biodegradation rates [11,31-33]. Bioaugmentation depends on the exogenously added microorganisms, their tolerance to the pollutant, and their capacity to survive in the polluted environment. There are various strategies of bioaugmentation: the use of a single strain [34], a microbial consortium [35], and genetically engineered microorganisms [36]. Nwankwegu et al. (2017) evaluated TPH (total petroleum hydrocarbon) degradation in polluted soil with two different microorganisms, Micrococcus luteus and Rhizopus arrhizus, as well as with a consortium of both microorganisms. After 8 weeks, the TPH removal was $75.70 \%, 71.10 \%$, and $66.40 \%$, respectively. It is important to note that there was no statistical difference among the bioaugmentation options [37]. Poi et al. (2017) reported on a commercial-scale bioremediation of petroleum-contaminated soil using bioaugmentation treatment that included 22 bacterial strains. Laboratory experiments showed complete petroleum biodegradation within 21 days. Field experiments with initial petroleum hydrocarbon concentrations of 26,240, 622,657, and $978,399 \mathrm{mg} \mathrm{kg}^{-1}$ in 250 tons of soil resulted in petroleum degradation to less than $1000 \mathrm{mg} \mathrm{kg}^{-1}$ in 9,12 , and 17 weeks, respectively [38]. 


\subsection{Biofilm Formation on Plasma-Treated and Nontreated Wood Waste}

Cell immobilization is a well-known method in biological processes for producing metabolites and for wastewater treatment. It provides a high density of microbial population and long-term bacterial survival, leading to a high biodegradation rate [39-41]. Recent research showed that exposing wood waste to cold low-pressure nitrogen plasma led to an increase of the wood-waste surface hydrophilicity. In addition, a significant change in the wood-waste morphology was observed, which indicated probable enhancement of the wood-waste surface area. It was also reported that plasma treatment led to an increase of the bacterial attachment and biofilm formation. Biofilms of Pseudomonas putida and Bacillus cereus that were grown on plasma-pretreated wood waste led to $91 \%$ and $89 \%$ toluene degradation, respectively; whereas biofilms that were grown on untreated wood waste led to toluene degradation of only $78 \%$ and $58 \%$, respectively [24].

In our current research, wood waste was plasma-treated in order to use it as a carrier for biofilm to degrade diesel in contaminated soil. Examination of biofilm formation by the obtained diesel-degrading bacterial consortium on plasma-treated and nontreated wood waste was conducted for 7 days. Ten chips of wood waste were inserted into a bottle containing a suspension of the obtained consortium $(0.2 \mathrm{OD}$ $590 \mathrm{~nm}$ ) in MMD supplied with $0.5 \%$ diesel $(v / v)$ as the sole carbon source. The biofilm viability was examined using MTT analysis. In this assay, the hydrogenases of the diesel-degrading bacteria reduced the MTT salts, and the obtained purple solution was measured by a spectrophotometer (Figure 2). Control samples of treated and nontreated wood waste in sterile MMD served to examine the reaction of the wood waste itself with the MTT salts. The optical density of these controls was reduced from the experimental samples shown in Figure 2.

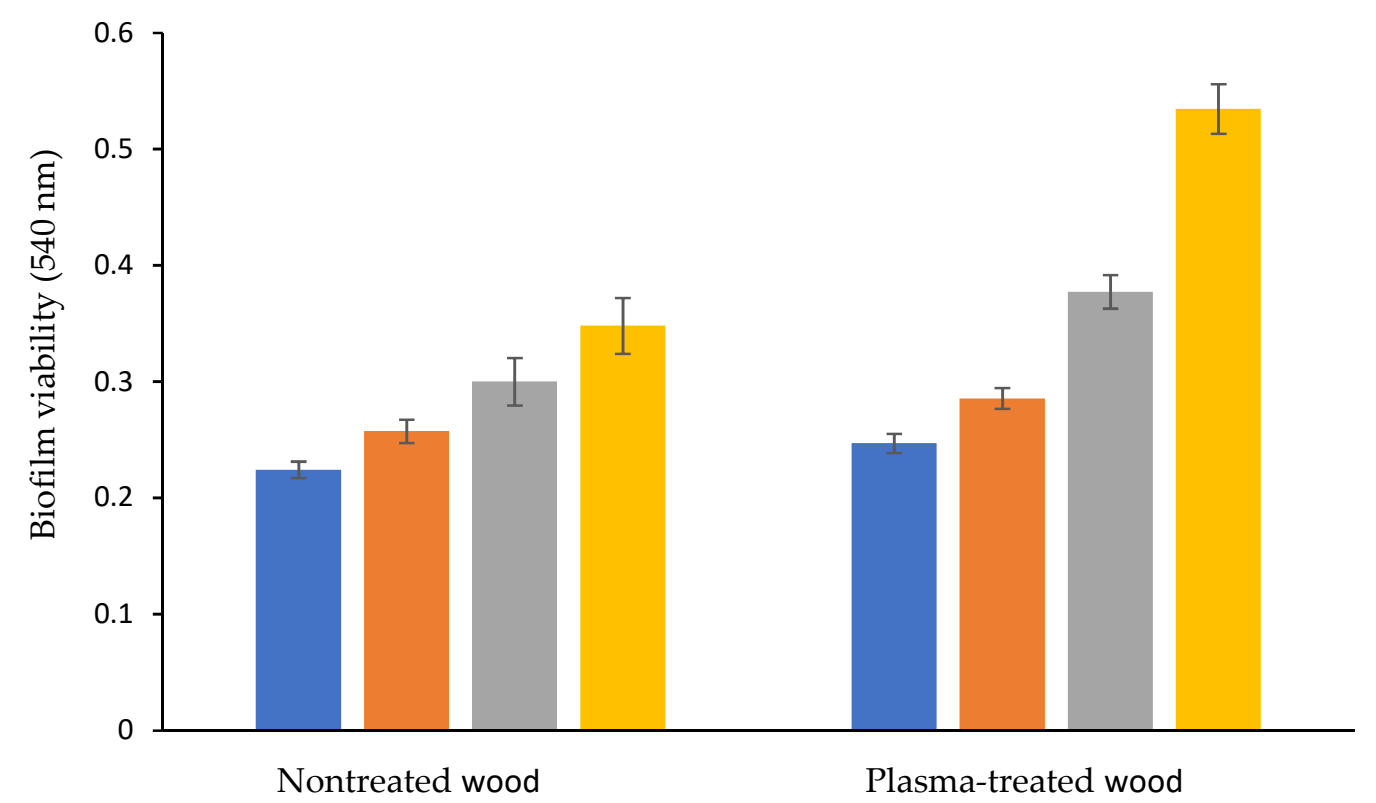

Figure 2. Biofilm viability on plasma-treated (right) and nontreated (left) wood waste. Measured on the 2nd (blue), 3rd (orange), 4th (grey), and 7th (yellow) day.

As can be seen, on the 7th day the biofilm viability on the plasma-treated wood waste reached $0.53 \pm 0.02$ OD $540 \mathrm{~nm}$, compared to the nontreated wood waste which was only $0.34 \pm 0.02$. Significantly higher viability on the plasma-treated wood waste, compared to the nontreated, was observed on the 4 th and 7 th days $(p<0.05)$.

Several methods have been suggested to increase diesel biodegradation rates in water source using immobilized or entrapped bacterial cells. Diesel-degrading microorganisms (Gordonia alkanivorans and Rhodococcus erythropolis) were immobilized in an entrapped matrix which included alginate and polyurethane-polyurea copolymer, with the addition of active carbon to strength the matrix 
structure. It was reported that under phosphorous-sufficient conditions, the TPH degradation was $80 \%$. Repeatable batch experiments indicated that the immobilized diesel-degrading bacteria were effective in seawater and groundwater for about 360 days [42]. Zeolites were used for biofilm formation and petroleum-hydrocarbon biodegradation of contaminated water. Biofilms grown on natural zeolite and ammonium-loaded zeolite (where $\mathrm{NH}_{4}$ was slowly released and served as the nutrient for the attached biofilm) were compared for diesel biodegradation efficacy. It was reported that the biofilm on the natural zeolite led to a decrease of TPH concentration, from 2.6 to $0.7 \mathrm{mg} \mathrm{L}^{-1}$ passing between 20 and 200 bed volumes. In contrast, with the ammonium-loaded zeolite the exit stream was below $0.2 \mathrm{mg}$ $\mathrm{L}^{-1}$ (passing 72 to 432 bed volumes), demonstrating higher TPH degradation in the presence of $\mathrm{NH}_{4}$ release [43]. The species Pseudomonas sp. and Brevundimonas sp. were isolated from oil-contaminated seawater and were immobilized on various surfaces (expanded perlite, expanded graphite, and bamboo charcoal). The advantage of biofilm in extreme conditions of salinity was showed by Wang et al., (2015). There, the oil removal rate of the immobilized bacteria was about $85 \%$ within 6 days. In addition, the immobilized bacteria displayed good salinity tolerance, compared with the planktonic bacteria [44].

\subsection{Diesel Concentration in Artificially Contaminated Soil}

Diesel emulsion was prepared using a homogenizer, followed by mixing it with Hamra soil $(0.15 \%$ and $0.60 \%$ diesel in $100 \mathrm{~g}$ soil) as described in Materials and Methods. Tubes with the artificially contaminated soil $(100 \mathrm{~g})$ were partially sealed and incubated at $37^{\circ} \mathrm{C}$; the residual diesel was examined for 4 weeks. As can be seen in Figure 3, soil samples that were contaminated with $0.15 \%$ diesel remained at this concentration until the fourth week. Similar results were obtained for the higher diesel concentration of $0.60 \%$. In addition, when the soil was contaminated with $0.15 \%$ and $0.60 \%$, the ratio between the different concentrations was maintained during the four weeks of the experiment. The maximum standard deviation was \pm 0.1 . The Hamra soil was collected from the university area and had not been previously exposed to oil components. Thus, we assume that the indigenous bacteria did not possess diesel biodegradation capabilities, at least within the four weeks of the experiment.

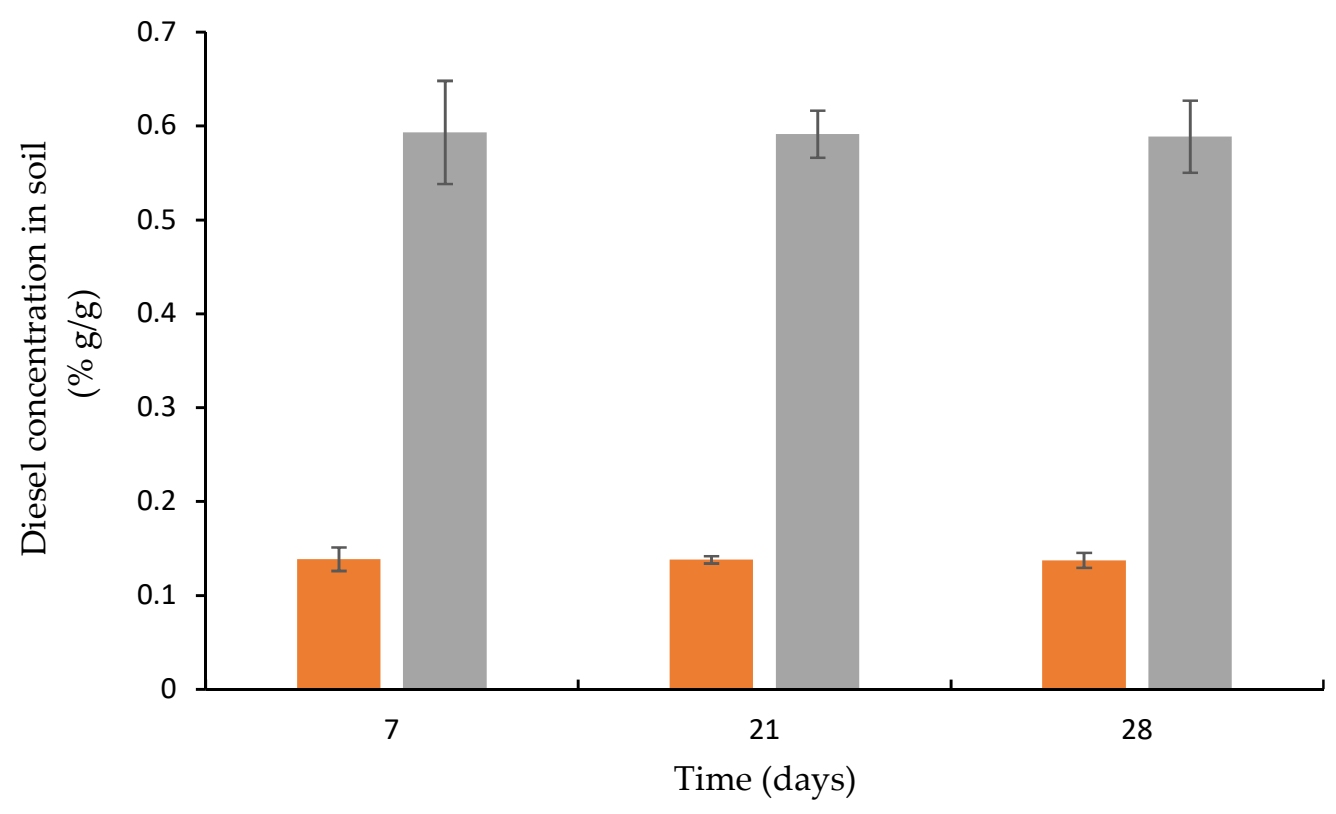

Figure 3. Diesel concentration in artificially contaminated soil: $0.15 \%$ (orange) and $0.6 \%$ (blue), \% (g/g).

It is important to note that when the soil was contaminated with a suspension of diesel that was not homogenized, the diversity of results was enormous. There was no correlation between the different initial diesel concentrations; moreover, different diesel concentrations were found in different places in the same sample of contaminated soil (data not shown). 
3.4. Diesel Concentration in Artificially Contaminated Soil Inoculated with Biofilm Attached to Plasma-Treated and Nontreated Wood Waste

Artificially diesel-contaminated soil was gently mixed with 10 chips of plasma-treated wood waste covered with biofilm. The same procedure was performed with biofilm attached to untreated wood waste. A control of diesel-contaminated soil was inoculated with a fresh planktonic bacterial consortium $(15 \mathrm{~mL})$ with the same optical density $(0.8$ OD $590 \mathrm{~nm})$ of the detached bacteria of the plasma-treated wood waste. Another two controls of plasma-treated and untreated wood waste were prepared for examination of the diesel absorbed by the wood waste itself (10 chips in $100 \mathrm{~g}$ diesel-contamination). All the experimental and control samples (each with 4 replicates) were incubated at $37^{\circ} \mathrm{C}$ for 4 weeks. The residual diesel was analyzed with a GC-FID device (Figure 4).

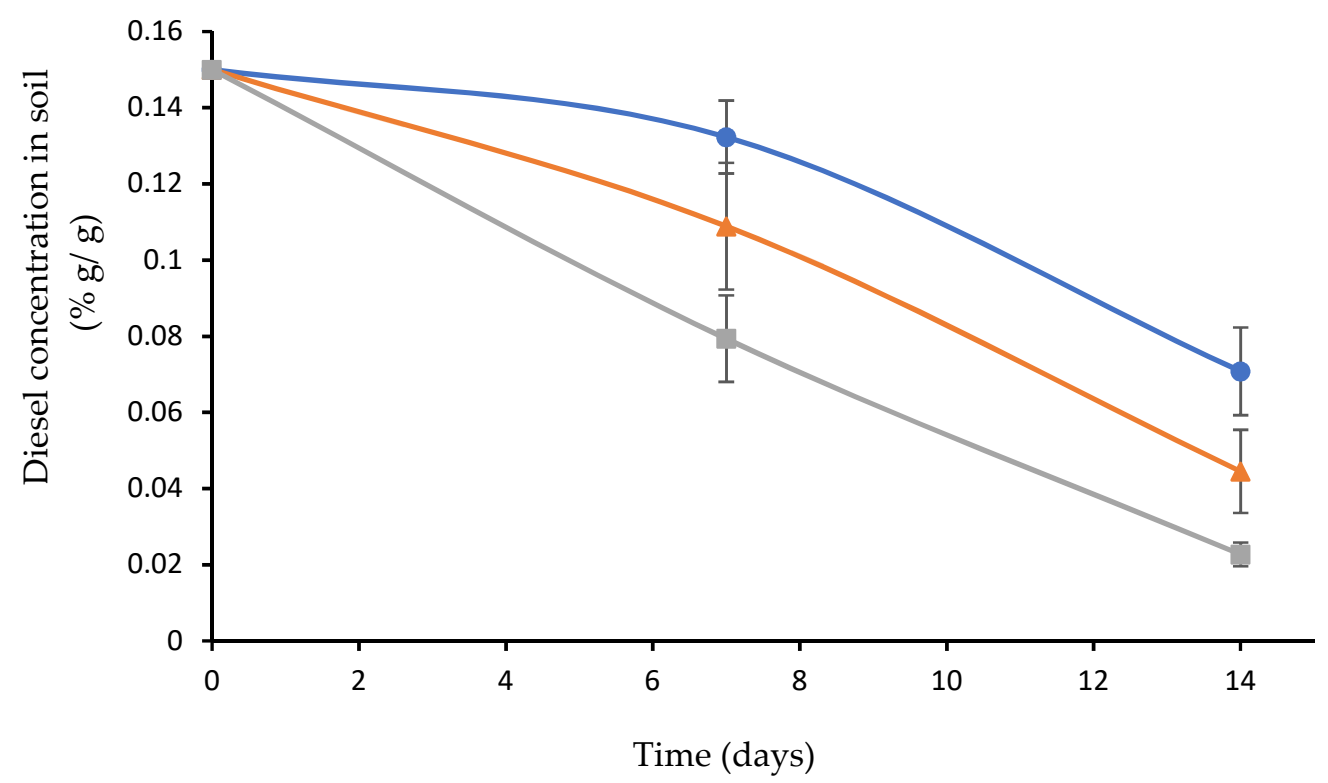

Figure 4. Diesel concentration when the contaminated soil was incubated at $37^{\circ} \mathrm{C}$ and inoculated with biofilm attached to plasma-treated wood waste (grey), biofilm attached to untreated wood waste (orange), and planktonic bacteria (blue).

The results showed that when the soil was inoculated with biofilm attached to plasma-treated wood waste, the residual diesel was only $13.3 \%$ with a degradation rate of $9.3 \mathrm{mg} \mathrm{day}^{-1}$. When the soil was inoculated with biofilm attached to the untreated wood waste, the residual diesel was $26.7 \%$ with a degradation rate of $7.8 \mathrm{mg} \mathrm{day}^{-1}$. In the soil samples inoculated with the planktonic bacteria, the residual concentration was much higher (46.7\%) with a degradation rate of only $5.7 \mathrm{mg} \mathrm{day}^{-1}$. These results indicate that the biofilm of the diesel-degrading consortium on the plasma-treated wood waste led to the highest diesel degradation rate. It is important to note that $5 \%$ of the diesel in the soil was absorbed into the wood waste itself (plasma-treated as well as untreated). The diesel concentration in the soil that was inoculated with the biofilm includes the $5 \%$ of the diesel absorbed by the wood waste. We assume that this parameter facilitated the diesel degradation and contributed to the degradation rate.

\subsection{Diesel Biodegradation as a Function of a Pre-Exposure to High Temperature}

The soil samples with the inoculated biofilm and planktonic bacteria were pretreated by exposure to $50{ }^{\circ} \mathrm{C}$ for 4 and $6 \mathrm{~h}$, followed by incubation at $37^{\circ} \mathrm{C}$ for the rest of the experiment (Figure 5a,b). 


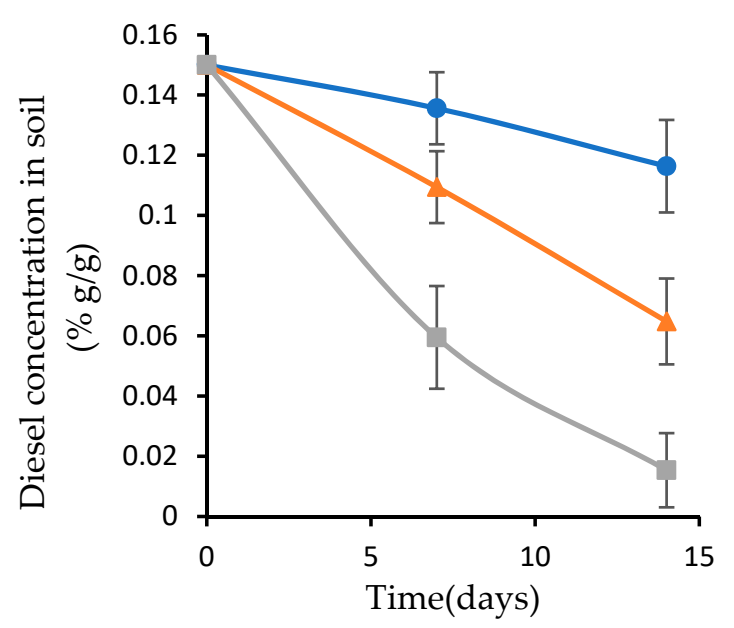

(a)

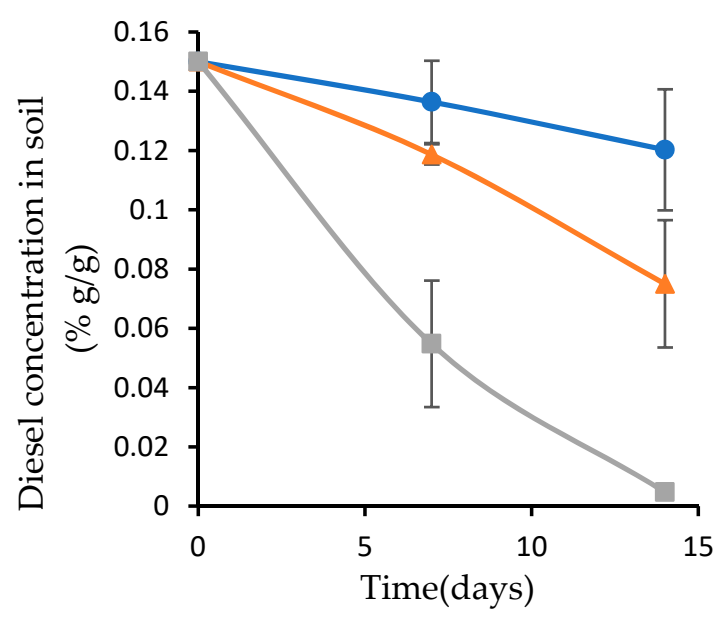

(b)

Figure 5. Diesel concentration in the inoculated soil pretreated at $50{ }^{\circ} \mathrm{C}$ for $4 \mathrm{~h} \mathrm{(a)}$, and $6 \mathrm{~h}(\mathbf{b})$, followed by incubation at $37^{\circ} \mathrm{C}$ for the rest of the experiment. Soil inoculated with biofilm attached to plasma-treated wood waste (grey); biofilm attached to nontreated wood waste (orange); and planktonic bacteria (blue).

When the inoculated soil was exposed to $50{ }^{\circ} \mathrm{C}$ for $4 \mathrm{~h}$ (Figure $5 \mathrm{a}$ ) and $6 \mathrm{~h}$ (Figure $5 \mathrm{~b}$ ), the diesel degradation rate by the biofilm attached to the plasma-treated wood waste was about the same as when the experiment was conducted at $37^{\circ} \mathrm{C}$. The biofilm on the untreated wood waste led to a degradation rate of $6.4 \mathrm{mg} \mathrm{day}^{-1}$ and $5 \mathrm{mg}^{\text {day }}{ }^{-1}$ when the experiment was performed at $50{ }^{\circ} \mathrm{C}$ for 4 and $6 \mathrm{~h}$, respectively. The degradation rate in the presence of planktonic bacteria was only $2 \mathrm{mg} \mathrm{day}^{-1}$ in both exposure duration times.

From these results it can be seen that the biofilm on plasma-pretreated wood waste led to the highest diesel biodegradation at all experimental temperatures, and that the degradation rate was not affected by the high temperature. The degradation rate of the biofilm on the untreated wood waste was minimally influenced by high temperature. This phenomenon can be explained by the fact that the bacteria in the biofilm are surrounded by a matrix containing extracellular polymeric substances (EPS), which provide resistance to high temperatures. In contrast, the planktonic bacteria were more sensitive to high temperature. The higher resistance of the biofilm that was attached to the plasma-pretreated wood waste, compared to the biofilm that was attached to the untreated wood waste, can be explained by the higher bacterial amount (Figure 2) and the relative distribution (Table 1). However, the planktonic bacterial consortium was highly affected by exposure to high temperatures, and its diesel-degrading rate was about 4.7-fold less, compared to the biofilm on the plasma-treated wood waste.

\subsection{Diesel Biodegradation as a Function of Soil Acidity}

The diesel-contaminated soil was adjusted to $\mathrm{pH} 5$ and $\mathrm{pH} 8$, and inoculated with the plasma-treated and nontreated wood waste covered with the biofilm, followed by incubation at $37^{\circ} \mathrm{C}$. A soil sample inoculated with the planktonic bacteria served as a control. The diesel biodegradation rates in the different $\mathrm{pH}$ values (Figure $6 \mathrm{a}, \mathrm{b}$ ) were compared to the degradation rate in the original, with $\mathrm{pH} 6.8$ (Figure 4). 


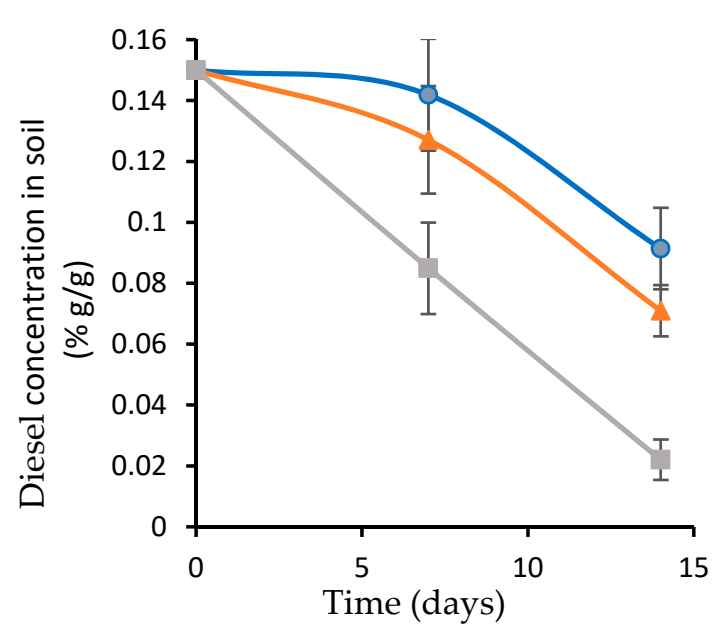

(a)

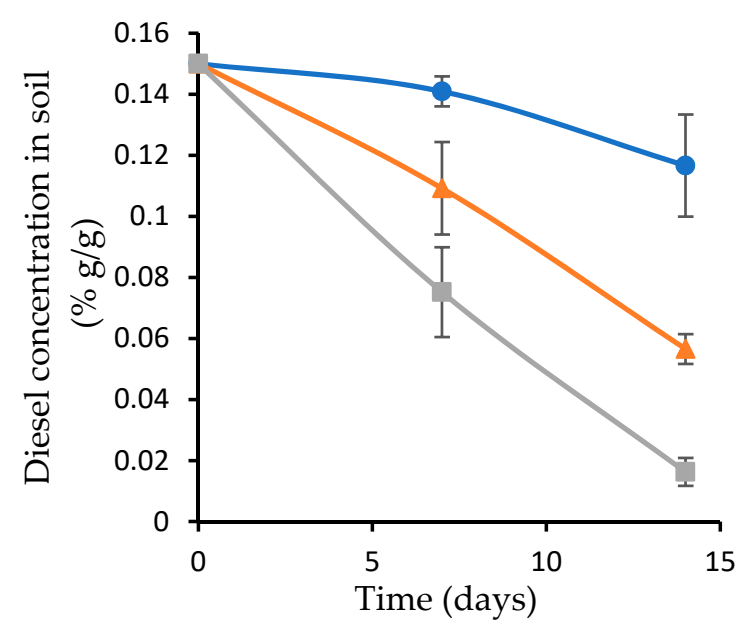

(b)

Figure 6. Diesel concentration as a function of soil acidity, $\mathrm{pH} 5$ (a) and $\mathrm{pH} 8$ (b). Soil that was inoculated with the plasma-treated wood waste covered with biofilm (grey); untreated wood waste covered with biofilm (orange); and planktonic bacteria (blue).

The biofilm attached to the plasma-treated wood waste that was inoculated in the soil adjusted to $\mathrm{pH} 5$, or to $\mathrm{pH} 8$, led to a diesel degradation rate of $9.3 \mathrm{mg} \mathrm{day}^{-1}$, the same as with the original soil ( $\mathrm{pH}$ 6.8). The biofilm on the untreated wood waste that was inoculated in soil adjusted to $\mathrm{pH} 5$ and $\mathrm{pH} 8$ led to a slight change in the degradation rate compared to the original soil: $5.7 \mathrm{mg}^{-1 a y^{-1}}$ and $6.5 \mathrm{mg}$ day $^{-1}$, respectively. The planktonic bacteria yielded a diesel degradation rate of only $4.3 \mathrm{mg} \mathrm{day}^{-1}$ at $\mathrm{pH} 5$, and $2.1 \mathrm{mg} \mathrm{day}^{-1}$ at $\mathrm{pH} 8$, while in the original soil ( $\mathrm{pH} 6.8$ ) it was $5.7 \mathrm{mg} \mathrm{day}^{-1}$.

To summarize, the diesel-degrading consortium was obtained from the desert, where soil temperatures in the summer can reach at least $44^{\circ} \mathrm{C}$ for several hours a day. When the planktonic bacteria were exposed to $50^{\circ} \mathrm{C}$ for 4 and $6 \mathrm{~h}$, a reduction in the diesel degradation rate was observed. However, the biofilm on the wood waste preserved its diesel-degrading activity even when the soil was exposed to $50{ }^{\circ} \mathrm{C}$ for $6 \mathrm{~h}$ (Figure 5). We assume that the difference in the diesel degradation rates between the biofilm grown on the plasma-treated wood waste and the biofilm grown on the untreated wood waste is due to the higher bacterial viability on the plasma-treated wood waste (Figure 2). The biofilm was also less affected by the change in the soil acidity, compared to the planktonic consortium (Figure 6).

Biodegradation of petroleum components was reported in cold as well as hot environments; this was ascribed to the adaptation of the indigenous microorganisms to the environmental temperature. The prevalence of several biodegrading $n$-alkanes, such as Pseudomonas putida, Acinetobacter spp., Rhodococcus spp., and Mycobacterium sp., were found in oil-contaminated Alpine soils. A significantly higher percentage of these bacteria was found in the contaminated (50 to $75 \%$ ) compared to the pristine (0 to $12.5 \%$ ) soils, confirming enrichment of the biodegrading microorganisms following contamination. A significant positive correlation was reported between the level of TPH contamination and the number of biodegrading $n$-alkanes bacteria. However, only partial correlation was found with the TPH contents [45]. Microorganisms able to degrade polycyclic aromatic hydrocarbons (PAHs) were isolated from the Unkeshwar hot spring in India. The obtained consortium (Aeribacillus pallidus, Bacillusaxarquiensis, Bacillus siamensis, and Bacillus subtilis subsp. inaquosorum) was found to be thermophilic and thermo-tolerant. This consortium produced a relatively high $\mathrm{PAH}$ degradation rate at $50{ }^{\circ} \mathrm{C}[46]$. 


\subsection{Microbial Distribution Analysis (Based on $16 S$ rRNA) in the Original Oil-Contaminated Site and in the Biofilms}

The microbial diversity in the original contaminated soil was evaluated based on $16 \mathrm{~S}$ rRNA. Operational taxonomic unit (OTU) reads were identified and phylogenetically classified. The predominant phylum was Proteobacteria (52\%), the second-most predominant was Actinobacteria $(18 \%)$, and the third was Firmicutes $(8 \%)$. The other phyla (40) each gave evidence of relatively low abundance. It is important to note the high prevalence of unassigned phyla (about $7 \%$ ), which may be attributed to either a significant amount of novel species or poorly identified taxonomy. Taxonomic classification at the order level revealed that the 10 most predominant orders were: Actinomycetales (16.6\%), Xanthomonadales (15.4\%), Bacillales (6.9\%), Sphingomonadales (5.2\%), Pseudomonadales (4.6\%), Rhizobiales (4.2\%), Rhodospirillales (3.3\%), Oceanospirillales (3.3\%), Chromatiales (2.6\%), and Burkholderiales (2.5\%). A total of 189 distinct orders and nearly 300 families were identified. Orders and families with low relative distribution (less than $3 \%$ ) were not taken into account for the percentage calculations.

Plasma-treated and untreated wood waste in MMD were inoculated with the obtained diesel-degrading consortium for 7 days. The bacterial distribution in the biofilm which was grown on the wood waste was analyzed by microbial $16 \mathrm{~S}$ rRNA. The bacterial distribution at the phylum level in the biofilm grown on the plasma-treated wood waste included a major phylum, Proteobacteria (82.8\%), and a minor phylum, Bacteroidetes (8.3\%); the rest (12 phyla) each showed relatively low abundance. The phyla diversity of the biofilm that was grown on the untreated wood waste was Proteobacteria (71.5\%) and Bacteroidetes (13\%); the rest (12 phyla) each showed relatively low abundance. The bacterial distribution at the class level in the biofilms grown on the plasma-treated and untreated wood waste included two main classes: $\gamma$-Proteobacteria (40.5\% and $30.4 \%$, respectively), and $\alpha$-Proteobacteria (34.4\% and $31.7 \%$, respectively). These phyla mainly included oil-degrading bacterial families ( 9 of the top 10 families): Xanthomonadaceae, Sphingomonadaceae, Chitinophagaceae, Rhodospirillaceae, Caulobacteraceae, Pseudomonadaceae, Bradyrhizobiaceae, Oxalobacteraceae and Sinobacteraceae, except for the mitochondria (Figure 7). The families' relative distribution, and references reporting their oil-degrading abilities, is shown in Table 1.

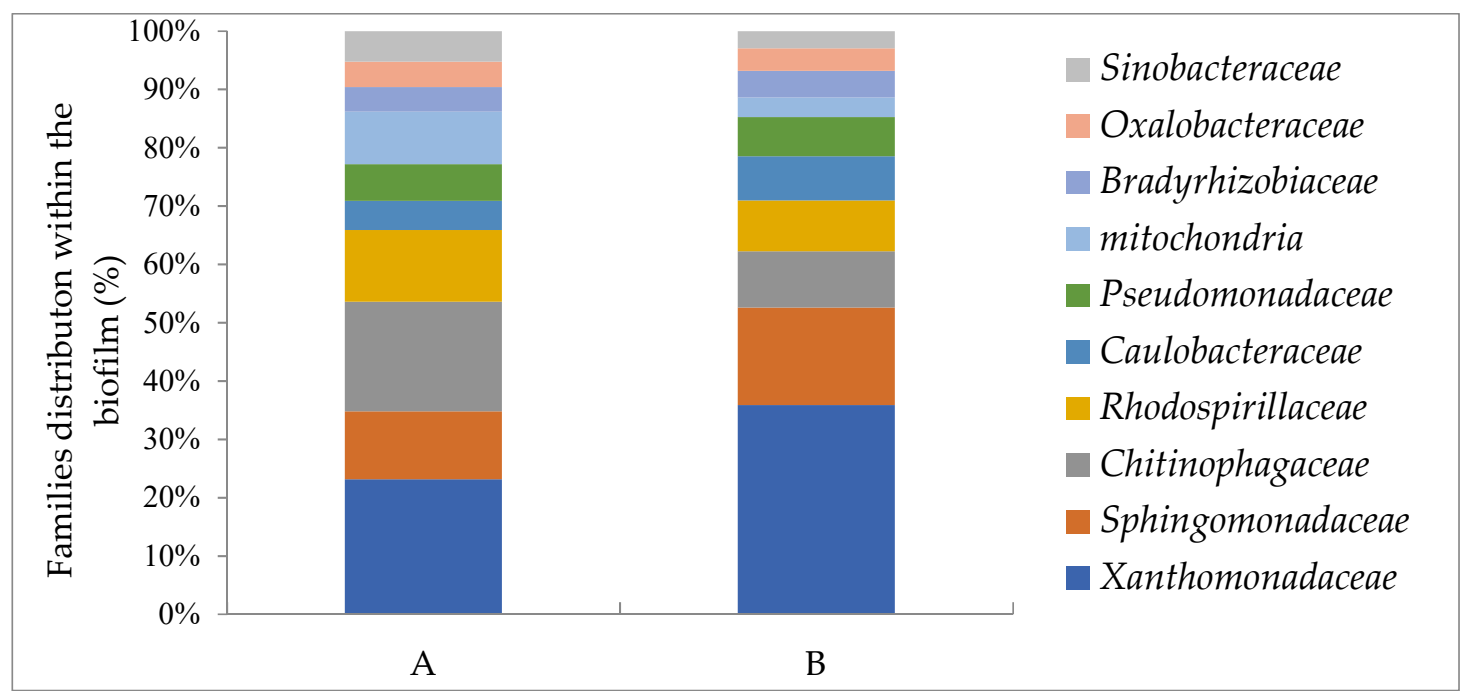

Figure 7. Bacterial distribution of the top 10 at the family level $(81 \%$ and $67.5 \%$, respectively of all identified families) which were identified in the biofilm grown on the plasma-treated (A) and untreated wood waste (B).

The bacterial distribution at the genus level in the biofilm attached to the plasma-treated and untreated wood waste was poorly identified. The major genus in the most abundant bacteria for the family Xanthomonadaceae was not identified (80\%). In this family the genera Lysobacter, 
Pseudoxanthomonas, and Thermomonas were identified and exhibited very low relative abundance of $20 \%$. In the family Sphingomonadaceae, a genus which exhibits relative abundant of $40 \%$ was not identified, while two other genera, Kaistobacter and Sphingomonas, exhibited relative abundance of $60 \%$.

To summarize, the most abundant phylum in the original diesel-contaminated soil was Proteobacteria (52\%). The abundance of this phylum was accelerated in the biofilm attached to plasma-treated and untreated wood waste that was grown in MM supplied with diesel: $82.8 \%$ and $71.5 \%$, respectively. The bacterial distribution at the family level showed that in the biofilm, the two most abundant were Xanthomonadaceae and Sphingomonadaceae. In the biofilm attached to the plasma-treated wood waste Xanthomonadaceae was $29 \%$, while on the untreated wood waste it was $16 \%$; in the original soil Xanthomonadaceae was only $4 \%$. The second most abundant family in the biofilm attached to plasma-treated and untreated wood waste was Sphingomonadaceae, $13 \%$ and $8 \%$, respectively.

An interesting finding showed a significantly higher distribution of diesel-degrading bacteria in the biofilm attached to the wood waste, compared to that found in the original soil (cited studies in Table 1). Nine of the 10 families which were found in the biofilm were reported to exhibit hydrocarbon biodegradation activity. We assume that the bacterial ability of biofilm formation also influenced on their relative distribution in the biofilm.

Table 1. Bacterial relative distribution at the family level of the top 10, relative to all identified families in the original diesel contaminated soil, within the biofilm grown on the plasma-treated and untreated wood waste.

\begin{tabular}{ccccc}
\hline Families & Soil (\%) & $\begin{array}{c}\text { Biofilm on the } \\
\text { Plasma-Treated } \\
\text { Wood Waste (\%) }\end{array}$ & $\begin{array}{c}\text { Biofilm on the } \\
\text { Untreated Wood } \\
\text { Waste (\%) }\end{array}$ & $\begin{array}{c}\text { Hydrocarbon } \\
\text { Activity Reported } \\
\text { Previously }\end{array}$ \\
\hline Xanthomonadaceae & 4 & 29 & 16 & {$[47,48]$} \\
Sphingomonadaceae & 3 & 13 & 8 & {$[49,50]$} \\
Chitinophagaceae & 0.29 & 8 & 13 & {$[51]$} \\
Rhodospirillaceae & 1 & 7 & 8 & {$[52,53]$} \\
Caulobacteraceae & 2 & 6 & 3 & {$[52]$} \\
Pseudomonadaceae & 4 & 6 & 4 & {$[53]$} \\
Bradyrhizobiaceae & 0.04 & 3 & 3 & {$[47]$} \\
mitochondria & 0.22 & 3 & 3 & {$[54]$} \\
Oxalobacteraceae & 0.04 & 2 & $66 \%$ & \\
Sinobacteraceae & 11 & $81 \%$ & 6 & \\
\hline sum & $26.09 \%$ & &
\end{tabular}

Prince et al. (2010) reported on hydrocarbon-degrading bacteria classified at the phylum level as Proteobacteria, Actinobacteria, Firmicutes, Bacteroidetes, Chlamydiae, and Deinococcus-Thermus [55]. In other studies, it was reported that hydrocarbonoclastic bacteria belonging to the phyla Actinobacteria, Proteobacteria, and Firmicutes have been widely distributed in oil-contaminated soil [56,57]. A significant increase in the relative distribution of Proteobacteria occurred in diesel-polluted soils after the second week, whereas other phyla decreased, especially Actinobacteria [57]. Bell et al. (2013) reported that Actinobacteria and Proteobacteria were dominant in hydrocarbon-contaminated Arctic soils [47].

Popp et al. (2006) previously reported on the predominance at the class level of $\gamma$-Proteobacteria in hydrocarbon-contaminated soil [58]. The same observation was found in petroleum refinery sludge [51]. Jung et al. (2014) evaluated red clay soil as a biostimulation agent in diesel-contaminated soils for diesel biodegradation and bacterial distribution evaluation. It was reported that more than $70 \%$ of the total community at the phyla level were Proteobacteria, Acidobacteria, and Actinobacteria. Meanwhile, Gemmatimonadetes, Chloroflexi, Nitrospira, Bacteroidetes, Planctomycetes, Firmicutes, and Cynobacteria accounted for approximately $10 \%$. A large portion, about $20 \%$, was accounted as unassigned bacteria. Taxonomic classification at the family level of diesel-contaminated soil indicated increases in Nocardioidaceae, Pseudomonadaceae, Xanthomonadaceae, and Caulobacteraceae [48]. 
In our study, the predominant phylum in the original oil-contaminated soil was Proteobacteria (52\%). The predominance of this phylum was accelerated to more than $70 \%$ in the biofilm which was grown in the presence of diesel, on the plasma-treated as well as untreated wood waste. We assume that the combination of several bacterial strains helped accelerate the biodegradation process.

However, the cited studies showed that other phyla were predominant as a consequence of oil-component contamination. It was further reported that the extent and dynamics of microbial distribution were found to be dependent on the soil type, the hydrocarbon composition, and the pollution time [59]. A drastic environmental disturbance such as a fire or pollution may cause huge changes in the bacterial diversity and its community structure [60].

To summarize, the innovative contribution of this study is that plasma-treated wood waste can serve for biofilm formation and enhance the bioremediation of diesel-contaminated soil. Moreover, this technology can be implemented for other toxic organic pollutants in soil. The advantages of this technology include the substratum for biofilm attachment being a natural material, and the plasma treatment being a clean technology that is not based on chemicals or extreme temperatures.

\section{Conclusions}

A diesel-degradable consortium that was obtained from oil-contaminated soil was grown on wood waste pretreated with plasma. The cold low-pressure nitrogen plasma treatment led to an increase of bacterial attachment and diesel degradation rates. On the 7th day of growth, the biofilm viability on the plasma-treated wood waste reached $0.53 \pm 0.02 \mathrm{OD} 540 \mathrm{~nm}$, compared to biofilm on the nontreated wood waste $(0.34 \pm 0.02)$. Biofilm attached to plasma-treated and untreated wood waste which was inoculated into artificially diesel-contaminated soil $(0.15 \% \mathrm{~g} / \mathrm{g})$ achieved degradation rates of $9.3 \mathrm{mg}$ day $^{-1}$ and $7.8 \mathrm{mg} \mathrm{day}^{-1}$, respectively. Meanwhile, in the soil inoculated with planktonic bacteria, the rate was only $5.7 \mathrm{mg} \mathrm{day}^{-1}$. Exposing the soil sample to high temperature $\left(50^{\circ} \mathrm{C}\right)$ for 4 and $6 \mathrm{~h}$ did not influence the degradation rate of the biofilm grown on the plasma-treated wood waste, whereas the degradation rate of the planktonic consortium was reduced three-fold. To our knowledge, this is the first study to show the advantage of biofilms attached to plasma-pretreated wood waste for diesel biodegradation in soil.

Author Contributions: Conceptualization and methodology, R.F. and R.C.; Contributed to the experiment, R.F. and A.R.; Experimental data analyzing, R.F.; Investigation, R.F. and A.R.; Research administration and supervision, R.C.; Writing—original draft preparation, R.F., R.C. and S.R.; Writing—review and editing, G.B. and S.R. All authors agreed on the final version of the manuscript.

Conflicts of Interest: The authors declare no conflict of interest.

\section{References}

1. Gallego, J.L.R.; Loredo, J.; Llamas, J.F.; Vázquez, F.; Sánchez, J. Bioremediation of diesel-contaminated soils: Evaluation of potential in situ techniques by study of bacterial degradation. Biodegradation 2001, 12, 325-335. [CrossRef] [PubMed]

2. Silverman, D.T.; Samanic, C.M.; Lubin, J.H.; Blair, A.E.; Stewart, P.A.; Vermeulen, R.; Coble, J.B.; Rothman, N.; Schleiff, P.L.; Travis, W.D.; et al. The Diesel Exhaust in Miners Study: A Nested Case-Control Study of Lung Cancer and Diesel Exhaust. JNCI J. Natl. Cancer Inst. 2012, 104, 855-868. [CrossRef] [PubMed]

3. Khan, F.I.; Husain, T.; Hejazi, R. An overview and analysis of site remediation technologies. J. Environ. Manag. 2004, 71, 95-122. [CrossRef] [PubMed]

4. Vidali, M. Bioremediation. An overview. Pure Appl. Chem. 2001, 73, 1163-1172. [CrossRef]

5. Donlan, R.M. Biofilms: microbial life on surfaces. Emerg. Infect. Dis. 2002, 8, 881-890. [CrossRef]

6. Swissa, N.; Nitzan, Y.; Anker, Y.; Cahan, R. Biofilter based on a biofilm immobilized on geo-textile sheets for rapid atrazine biodegradation. Int. Biodeterior. Biodegrad. 2015, 105, 146-152. [CrossRef]

7. Gomila, M.; Busquets, A.; García-Valdés, E.; Michael, E.; Cahan, R.; Nitzan, Y.; Lalucat, J. Draft Genome Sequence of the Toluene-Degrading Pseudomonas stutzeri Strain ST-9. Genome Announc. 2015, 3, e00567-15. [CrossRef] 
8. Michael, E.; Gomila, M.; Lalucat, J.; Nitzan, Y.; Pechatnikov, I.; Cahan, R. Proteomic Assessment of the Expression of Genes Related to Toluene Catabolism and Porin Synthesis in Pseudomonas stutzeri ST-9. J. Proteome Res. 2017, 16, 1683-1692. [CrossRef]

9. Innemanová, P.; Filipová, A.; Michalíková, K.; Wimmerová, L.; Cajthaml, T. Bioaugmentation of PAH-contaminated soils: A novel procedure for introduction of bacterial degraders into contaminated soil. Ecol. Eng. 2018, 118, 93-96. [CrossRef]

10. Sun, G.-D.; Xu, Y.; Jin, J.-H.; Zhong, Z.-P.; Liu, Y.; Luo, M.; Liu, Z.-P. Pilot scale ex-situ bioremediation of heavily PAHs-contaminated soil by indigenous microorganisms and bioaugmentation by a PAHs-degrading and bioemulsifier-producing strain. J. Hazard. Mater. 2012, 233-234, 72-78. [CrossRef]

11. Tahhan, R.A.; Ammari, T.G.; Goussous, S.J.; Al-Shdaifat, H.I. Enhancing the biodegradation of total petroleum hydrocarbons in oily sludge by a modified bioaugmentation strategy. Int. Biodeterior. Biodegrad. 2011, 65, 130-134. [CrossRef]

12. Teng, Y.; Luo, Y.; Sun, M.; Liu, Z.; Li, Z.; Christie, P. Effect of bioaugmentation by Paracoccus sp. strain HPD-2 on the soil microbial community and removal of polycyclic aromatic hydrocarbons from an aged contaminated soil. Bioresour. Technol. 2010, 101, 3437-3443. [PubMed]

13. Venkata Mohan, S.; Prasanna, D.; Purushotham Reddy, B.; Sarma, P.N. Ex situ bioremediation of pyrene contaminated soil in bio-slurry phase reactor operated in periodic discontinuous batch mode: Influence of bioaugmentation. Int. Biodeterior. Biodegrad. 2008, 62, 162-169. [CrossRef]

14. Thomassin-Lacroix, E.; Eriksson, M.; Reimer, K.; Mohn, W. Biostimulation and bioaugmentation for on-site treatment of weathered diesel fuel in Arctic soil. Appl. Microbiol. Biotechnol. 2002, 59, 551-556.

15. Launen, L.A.; Buggs, V.H.; Eastep, M.E.; Enriquez, R.C.; Leonard, J.W.; Blaylock, M.J.; Huang, J.-W.; Häggblom, M.M. Bioremediation of Polyaromatic Hydrocarbon-Contaminated Sediments in Aerated Bioslurry Reactors. Bioremediat. J. 2002, 6, 125-141. [CrossRef]

16. Silva, Í.S.; dos Santos, E.D.; de Menezes, C.R.; de Faria, A.F.; Franciscon, E.; Grossman, M.; Durrant, L.R. Bioremediation of a polyaromatic hydrocarbon contaminated soil by native soil microbiota and bioaugmentation with isolated microbial consortia. Bioresour. Technol. 2009, 100, 4669-4675. [CrossRef]

17. Mrozik, A.; Piotrowska-Seget, Z. Bioaugmentation as a strategy for cleaning up of soils contaminated with aromatic compounds. Microbiol. Res. 2010, 165, 363-375. [CrossRef]

18. Kjelleberg, S.; Molin, S. Is there a role for quorum sensing signals in bacterial biofilms? Curr. Opin. Microbiol. 2002, 5, 254-258. [CrossRef]

19. Stoodley, P.; Cargo, R.; Rupp, C.J.; Wilson, S.; Klapper, I. Biofilm material properties as related to shear-induced deformation and detachment phenomena. J. Ind. Microbiol. Biotechnol. 2002, 29, 361-367. [CrossRef]

20. Kumar, C.G.; Anand, S.K. Significance of microbial biofilms in food industry: a review. Int. J. Food Microbiol. 1998, 42, 9-27. [CrossRef]

21. Koch, B.; Worm, J.; Jensen, L.E.; Højberg, O.; Nybroe, O. Carbon limitation induces sigma(S)-dependent gene expression in Pseudomonas fluorescens in soil. Appl. Environ. Microbiol. 2001, 67, 3363-3370. [CrossRef] [PubMed]

22. Schechter, M.; Schechter, A.; Rozenfeld, S.; Efrat, E.; Cahan, R. Anode Biofilm. In Technology and Application of Microbial Fuel Cells; Chin-Tgan, W., Ed.; IntechOpen: London, UK, 2014; pp. 57-75.

23. Svensson, S.L.; Pryjma, M.; Gaynor, E.C. Flagella-Mediated Adhesion and Extracellular DNA Release Contribute to Biofilm Formation and Stress Tolerance of Campylobacter jejuni. PLoS ONE 2014, 9, e106063. [CrossRef] [PubMed]

24. Farber, R.; Dabush-Busheri, I.; Chaniel, G.; Rozenfeld, S.; Bormashenko, E.; Multanen, V.; Cahan, R. Biofilm grown on wood waste pretreated with cold low-pressure nitrogen plasma: Utilization for toluene remediation. Int. Biodeterior. Biodegradation 2019, 139, 62-69. [CrossRef]

25. Dursun, A.Y.; Tepe, O. Internal mass transfer effect on biodegradation of phenol by Ca-alginate immobilized Ralstonia eutropha. J. Hazard. Mater. 2005, 126, 105-111. [CrossRef]

26. Abu-Salah, K.; Shelef, G.; Levanon, D.; Armon, R.; Dosoretz, C.G. Microbial degradation of aromatic and polyaromatic toxic compounds adsorbed on powdered activated carbon. J. Biotechnol. 1996, 51, 265-272. [CrossRef]

27. Yordanova, G.; Ivanova, D.; Godjevargova, T.; Krastanov, A. Biodegradation of phenol by immobilized Aspergillus awamori NRRL 3112 on modified polyacrylonitrile membrane. Biodegradation 2009, 20, 717-726. [CrossRef] 
28. Cahan, R.; Stein, M.; Anker, Y.; Langzam, Y.; Nitzan, Y. Innovative utilization of coal bottom ash for bioremediation of toxic organic pollutants. Int. Biodeterior. Biodegrad. 2013, 85, 421-428. [CrossRef]

29. Bormashenko, E.; Chaniel, G.; Grynyov, R. Towards understanding hydrophobic recovery of plasma treated polymers: Storing in high polarity liquids suppresses hydrophobic recovery. Appl. Surf. Sci. 2013, 273, 549-553. [CrossRef]

30. Carter, M.R.; Gregorich, E.G. Soil Sampling and Methods of Analysis, 2nd ed.; Taylor \& Francis Group, LLC: Boca Raton, FL, USA, 2008.

31. Sayara, T.; Sarrà, M.; Sánchez, A. Preliminary screening of co-substrates for bioremediation of pyrene-contaminated soil through composting. J. Hazard. Mater. 2009, 172, 1695-1698. [CrossRef]

32. Sayara, T.; Sarrà, M.; Sánchez, A. Effects of compost stability and contaminant concentration on the bioremediation of PAHs-contaminated soil through composting. J. Hazard. Mater. 2010, 179, 999-1006. [CrossRef]

33. Betancur-Galvis, L.A.; Alvarez-Bernal, D.; Ramos-Valdivia, A.C.; Dendooven, L. Bioremediation of polycyclic aromatic hydrocarbon-contaminated saline-alkaline soils of the former Lake Texcoco. Chemosphere 2006, 62, 1749-1760. [CrossRef] [PubMed]

34. Wang, L.; Chi, X.-Q.; Zhang, J.-J.; Sun, D.-L.; Zhou, N.-Y. Bioaugmentation of a methyl parathion contaminated soil with Pseudomonas sp. strain WBC-3. Int. Biodeterior. Biodegrad. 2014, 87, 116-121. [CrossRef]

35. Ghazali, F.M.; Rahman, R.N.Z.A.; Salleh, A.B.; Basri, M. Biodegradation of hydrocarbons in soil by microbial consortium. Int. Biodeterior. Biodegrad. 2004, 54, 61-67. [CrossRef]

36. Rodrigues, J.L.M.; Kachel, C.A.; Aiello, M.R.; Quensen, J.F.; Maltseva, O.V.; Tsoi, T.V.; Tiedje, J.M. Degradation of Aroclor 1242 Dechlorination Products in Sediments by Burkholderia xenovorans LB400(ohb) and Rhodococcus sp. Strain RHA1(fcb). Appl. Environ. Microbiol. 2006, 72, 2476-2482. [CrossRef]

37. Nwankwegu, A.S.; Onwosi, C.O. Bioremediation of gasoline contaminated agricultural soil by bioaugmentation. Environ. Technol. Innov. 2017, 7, 1-11. [CrossRef]

38. Poi, G.; Aburto-Medina, A.; Mok, P.C.; Ball, A.S.; Shahsavari, E. Large scale bioaugmentation of soil contaminated with petroleum hydrocarbons using a mixed microbial consortium. Ecol. Eng. 2017, 102, 64-71. [CrossRef]

39. Gallo, M.; Speranza, B.; Corbo, M.R.; Sinigaglia, M.; Bevilacqua, A. Novel Microbial Immobilization Techniques. In Novel Food Fermentation Technologies; Springer: Cham, Switzerland, 2016; pp. 35-55.

40. Das, N.; Chandran, P. Microbial Degradation of Petroleum Hydrocarbon Contaminants: An Overview. Biotechnol. Res. Int. 2011, 2011,1-13. [CrossRef]

41. Kuyukina, M.S.; Ivshina, I.B.; Serebrennikova, M.K.; Krivorutchko, A.B.; Podorozhko, E.A.; Ivanov, R.V.; Lozinsky, V.I. Petroleum-contaminated water treatment in a fluidized-bed bioreactor with immobilized Rhodococcus cells. Int. Biodeterior. Biodegrad. 2009, 63, 427-432. [CrossRef]

42. Chen, W.; Li, J.; Sun, X.; Min, J.; Hu, X. High efficiency degradation of alkanes and crude oil by a salt-tolerant bacterium Dietzia species CN-3. Int. Biodeterior. Biodegrad. 2017. [CrossRef]

43. Freidman, B.L.; Gras, S.L.; Snape, I.; Stevens, G.W.; Mumford, K.A. The performance of ammonium exchanged zeolite for the biodegradation of petroleum hydrocarbons migrating in soil water. J. Hazard. Mater. 2016, 313, 272-282. [CrossRef]

44. Wang, X.; Wang, X.; Liu, M.; Bu, Y.; Zhang, J.; Chen, J.; Zhao, J. Adsorption-synergic biodegradation of diesel oil in synthetic seawater by acclimated strains immobilized on multifunctional materials. Mar. Pollut. Bull. 2015, 92, 195-200. [CrossRef] [PubMed]

45. Margesin, R.; Labbé, D.; Schinner, F.; Greer, C.W.; Whyte, L.G. Characterization of Hydrocarbon-Degrading Microbial Populations in Contaminated and Pristine Alpine Soils. Appl. Environ. Microbiol. 2003, 69, 3085-3092. [CrossRef] [PubMed]

46. Mehetre, G.T.; Dastager, S.G.; Dharne, M.S. Biodegradation of mixed polycyclic aromatic hydrocarbons by pure and mixed cultures of biosurfactant producing thermophilic and thermo-tolerant bacteria. Sci. Total Environ. 2019, 679, 52-60. [CrossRef] [PubMed]

47. Bell, T.H.; Yergeau, E.F.; Juck, D.G.; Whyte, L.W.; Greer, C. Alteration of microbial community structure affects diesel biodegradation in an Arctic soil. FEMS Microbiol. Ecol. 2013, 85, 51-61. [CrossRef] [PubMed]

48. Jung, J.; Choi, S.; Hong, H.; Sung, J.-S.; Park, W. Effect of Red Clay on Diesel Bioremediation and Soil Bacterial Community. Microb. Ecol. 2014, 68, 314-323. [CrossRef] 
49. Gran-Scheuch, A.; Fuentes, E.; Bravo, D.M.; Jiménez, J.C.; Pérez-Donoso, J.M. Isolation and Characterization of Phenanthrene Degrading Bacteria from Diesel Fuel-Contaminated Antarctic Soils. Front. Microbiol. 2017, 8, 1634. [CrossRef]

50. Garrido-Sanz, D.; Redondo-Nieto, M.; Guirado, M.; Pindado Jiménez, O.; Millán, R.; Martin, M.; Rivilla, R. Metagenomic Insights into the Bacterial Functions of a Diesel-Degrading Consortium for the Rhizoremediation of Diesel-Polluted Soil. Genes Basel 2019, 10. [CrossRef]

51. Sarkar, J.; Kazy, S.K.; Gupta, A.; Dutta, A.; Mohapatra, B.; Roy, A.; Bera, P.; Mitra, A.; Sar, P. Biostimulation of Indigenous Microbial Community for Bioremediation of Petroleum Refinery Sludge. Front. Microbiol. 2016, 7, 1407. [CrossRef]

52. Fuentes, S.; Barra, B.; Caporaso, J.G.; Seeger, M. From Rare to Dominant: A Fine-Tuned Soil Bacterial Bloom during Petroleum Hydrocarbon Bioremediation. Appl. Environ. Microbiol. 2016, 82, 888-896. [CrossRef]

53. Jung, J.; Philippot, L.; Park, W. Metagenomic and functional analyses of the consequences of reduction of bacterial diversity on soil functions and bioremediation in diesel-contaminated microcosms. Sci. Rep. 2016, 6, 23012. [CrossRef]

54. Korotkevych, O.; Josefiova, J.; Praveckova, M.; Cajthaml, T.; Stavelova, M.; Brennerova, M.V. Functional adaptation of microbial communities from jet fuel-contaminated soil under bioremediation treatment: simulation of pollutant rebound. FEMS Microbiol. Ecol. 2011, 78, 137-149. [CrossRef] [PubMed]

55. Prince, R.C.; Gramain, A.; McGenity, T.J. Prokaryotic Hydrocarbon Degraders. In Handbook of Hydrocarbon and Lipid Microbiology; Springer Berlin Heidelberg: Berlin, Heidelberg, 2010; pp. 1669-1692.

56. Yang, S.; Wen, X.; Jin, H.; Wu, Q. Pyrosequencing Investigation into the Bacterial Community in Permafrost Soils along the China-Russia Crude Oil Pipeline (CRCOP). PLoS ONE 2012, 7, e52730. [CrossRef] [PubMed]

57. Fuentes, S.; Méndez, V.; Aguila, P.; Seeger, M. Bioremediation of petroleum hydrocarbons: catabolic genes, microbial communities, and applications. Appl. Microbiol. Biotechnol. 2014, 98, 4781-4794. [CrossRef] [PubMed]

58. Popp, N.; Schlomann, M.; Mau, M. Bacterial diversity in the active stage of a bioremediation system for mineral oil hydrocarbon-contaminated soils. Microbiology 2006, 152, 3291-3304. [CrossRef]

59. Hamamura, N.; Ward, D.M.; Inskeep, W.P. Effects of petroleum mixture types on soil bacterial population dynamics associated with the biodegradation of hydrocarbons in soil environments. FEMS Microbiol. Ecol. 2013, 85, 168-178. [CrossRef]

60. Ferrenberg, S.; O'neill, S.P.; Knelman, J.E.; Todd, B.; Duggan, S.; Bradley, D.; Robinson, T.; Schmidt, S.K.; Townsend, A.R.; Williams, M.W.; et al. Changes in assembly processes in soil bacterial communities following a wildfire disturbance. ISME J. 2013, 7, 1102-1111. [CrossRef] 